\title{
Recovery of Chromium from the Tannery Wastewater by Use of Bacillus Subtilis in Gujranwala, Pakistan
}

\author{
${ }^{1 *}$ Shazia Shafaat Adeel, ${ }^{1}$ Amina Wajid, ${ }^{1}$ Shahzad Hussain, ${ }^{1}$ Farnaz Malik, \\ ${ }^{1}$ Zumra Sami, ${ }^{1}$ Ikram Ul Haq, ${ }^{2}$ Abdul Hameed, ${ }^{1}$ Rafiq A Channa \\ ${ }^{I}$ National Institute of Health, Islamabad-45500, Pakistan \\ ${ }^{2}$ Department of Microbiology, Quaid-i-Azam University Islamabad, Pakistan
}

\begin{abstract}
Tanneries discharge wastes without any treatments on the vast areas of vacant land around them. Untreated effluents contain toxic materials like hexavalent chromium and sulphides which accumulate in soils and cause many health hazards. Hexavalent chromium is toxic and carcinogenic and is being extensively used in the tanning industry of Pakistan. The tannery wastewater samples were collected from two tanneries in Gujranwala, Pakistan. Chromium in these samples was determined using fractionation technique, spectrophotometry and MIBK extraction procedure. These samples were analyzed to recover chromium and chrome cake was purified using chemical treatment which can be used in recycling process. Enzyme was used to recover chromium from the samples. Two strains $S_{1}$ and $S_{2}$ of the Bacillus subtilis (isolated and identified from soil and tannery wastewater respectively) were used for enzymatic processing. Isolates were screened for extracellular protease activity. The strain $S_{2}$ of the Bacillus subtilis showed maximum zones of hydrolysis $(2.3 \mathrm{~cm})$ and proteolytic activity of $107 \mathrm{PU} / \mathrm{ml}$ at $65^{\circ} \mathrm{C}$ temperature, $150 \mathrm{rpm}$ agitation speed and7.5 $\mathrm{pH}$ on Shake Flask Fermentation. The One-step and the Two-step methods were employed for chromium recovery using the $S_{2}$ strain of the Bacillus subtilis. From the One-step method $96 \%$ chromium was recovered from sample-A and $92 \%$ from the sample-B. From the Two-step method of chromium recovery $98 \%$ of chromium was recovered from the sample-A and $97 \%$ from the sample-B. This paper evaluates the alternative treatment options used to treat, recover or recycle chromium from the waste water in order to minimize the environmental pollution.
\end{abstract}

Key words: Bacillus subtilis, Chromium, One Step and Two Step Methods, Pakistan, tannery wastewater.

\section{Introduction}

Environmental pollution has been a foremost irritation to industrial development. Chemical-based industries are the prime targets of the environmentalists for their battle against pollution. The leather sector of Pakistan is one of the oldest sector. It has an established share in world market for tanned leather, leather garments and leather gloves. At present there are 720 tanneries in Pakistan which generated the exports of US \$ 01 billion in year 2008-2009. The wastewater as result of tanning process is an important source adding $\mathrm{Cr}$ pollutent to the environment which causes many health hazards to all sort of life. The pressure by the environment protection agencies is so that it has become a common occurrence that the tanneries are forced to close down not only in developed countries but also in the developing countries. Chromium (III) salts are the most widely used chemicals for tanning processes, but $60 \%-70 \%$ of total chromium salts reacts with the hides. In the other words, about $30 \%-40 \%$ of the chromium amount remains in the solids and liquid wastes (especially spent tanning solutions). One ton of wet salted hide yields only $200 \mathrm{~kg}$ of leather, but more than $50 \mathrm{~m}^{3}$ of waste water ${ }^{[1 \& 5] .}$ Therefore, the removal and recovery of the chromium content of these wastewaters is necessary for environmental protection and economic reasons. Since the untreated effluents contain toxic materials like chromium and sulphides which accumulate in soils and cause many health hazards. For instance, according to an official report of the Environmental Protection Department Punjab (1997), the drinking water supplied by the municipality in Kasur (Pakistan) was found polluted with a high level of chromium. The diseases found, among the workers of tanning industry and residents of Kasur, were skin irritation, diarrhea, heart burning, respiratory tract infection, severe cough, fever and loss of eyesight. Lung cancer, high blood pressure, and kidney failure were the reported causes of death in many cases ${ }^{[36]}$. National Toxicology Program (NTP) study, inspected and observed the mid-term toxicity of chromium VI to rats and mice. The test animals were injected sodium dichromate in their drinking water for 3 months, and as result focal ulceration, metaplasia, and hyperplasia of the glandular stomach were found on both rats and mice. histiocytic infiltration of liver, duodenum, and pancreatic lymph nodes was also detected. Rats also showed an increase in lung and spleen weight and in macrophage activity ${ }^{[25]}$. Thus leather industry is pressurized to look for cleaner options. The effluents of these industries contain chromium at concentrations ranging from tenths to hundreds of milligrams per liter ${ }^{[6]}$. The current activity indicates that the trend is more towards design and utilization of cleaner and safer technologies 
Recovery of chromium from the tannery wastewater by use of Bacillus subtilis in Gujranwala,

like the enzymatic process ${ }^{[3 \& 31]}$. Chromium (III) salts are efficiently used as tanning agents in the leather industry. When waste is disposed off on soil, the risk of potential oxidation of chromium (III) to the hazardous hexavalent state exists in the presence of manganese (IV) oxide ${ }^{[20]}$. Among the two species Cr6+ is more toxic than $\mathrm{Cr} 3+{ }^{[28]}$ and is a serious environmental pollutant due to its wide use in different industries. It also effects the seed germination, seedling growth, pigments and enzymes content ${ }^{[10]}$. The removal of chromates from industrial wastewater effluents through Rhizopus oryzae indicates a feasible, economical technique for their removal ${ }^{[29]}$.

Heavy metal removals from waste streams are not cost effective ${ }^{[9]}$ and hence biological approach has been considered as an alternative remediation for heavy metal contamination. Recently microbial systems like fungus, bacteria and algae have been successfully used as adsorbing agents for removal of heavy metals ${ }^{[18,19,21}$ \& 34]. Microbial populations in metal polluted environments adapt to toxic concentrations of heavy metals and become metal resistant [22]. Different species of Aspergillus, Pseudomonas, Sporophyticus, Bacillus, Phanerochaete, etc., have been reported as efficient chromium and nickel reducers ${ }^{[8 \& 39]}$. Microorganisms play a significant role in bioremediation of heavy metal contaminated soil and waste water ${ }^{[27]}$.

In a study conducted ${ }^{[7]}$ in Pakistan has used different Bacillus sp., and Aspergillus niger isolates chosen after determination of maximum resistivity level against hexavalent chromium, were further accessed for their Cr6+ biosorptive capability for metal removal from aqueous solution. The present study was conducted with two strains of the Bacillus subtilis to test the efficiency of the enzyme in the recovery of chromium from the wastewater collected from two tanneries of the Pakistan which is not just affordable but also environment friendly.

\section{Materials and Methods}

\subsection{Samples:}

The two samples, one dark bluish green in color (A) from the tanning stage and the other light yellow (B) with a pungent odor from the last stage (after the formation of crust leather), were collected from the tanneries in Gujranawala, Pakistan.

\subsection{Stages of study:}

The study was divided in two steps

2.2.1 Determination of chromium in the samples

2.2.2 Recovery of Chromium from waste water

\subsection{Reagents:}

Distilled water, MIBK (methyl iso-butyl ketone), $\mathrm{K}_{2} \mathrm{Cr}_{2} \mathrm{O}_{7}, \mathrm{~K}_{2} \mathrm{CrO}_{4}, \mathrm{KH}_{2} \mathrm{PO}_{4}, \mathrm{H}_{2} \mathrm{SO}_{4}, \mathrm{CH}_{3} \mathrm{COOH}$, $\mathrm{NH}_{4} \mathrm{Cl}, \mathrm{Na}_{4} \mathrm{P}_{2} \mathrm{O}_{7}, \mathrm{NH}_{2} \mathrm{OH} \times \mathrm{HCl}, \mathrm{HNO}_{3}, \mathrm{HNO}_{3} \times \mathrm{HCLO}_{4}, \mathrm{Na}_{2} \mathrm{~S}_{2} \mathrm{O}_{4}$, Phosphoric acid, 1,5 diphenyl carbazide, membrane filters of pore size $0.01,0.45,0.1,0.05,0.2, \mu \mathrm{m}$ and Whatman \# 1 .

\subsubsection{Determination of Total Water-Soluble $\mathrm{Cr}$ and $\mathrm{Cr}(\mathrm{Vl})$ in Wastewater:}

Potassium dichromate $\left(\mathrm{K}_{2} \mathrm{Cr}_{2} \mathrm{O}_{7}\right)$ was used as standard $\mathrm{Cr}$ determinant. Two ml each of the sample (A and B) were shaken with $20 \mathrm{ml}$ distilled water and $20 \mathrm{ml}$ potassium dihydrogen phosphate $\left(\mathrm{KH}_{2} \mathrm{PO}_{4}, 0.015 \mathrm{~mol} /\right.$ $\mathrm{dm}^{.3}$ ) for 8 hours in the classical shaker and for 5 minutes in the ultrasonic homiginizer. The samples were centrifuged at $10,000 \mathrm{rpm}$ for 20 minutes at $25^{\circ} \mathrm{C}$ and filtered through membrane filters of pore size $(0.2-0.01$ $\mu \mathrm{m})$. The concentrations of total water-soluble chromium were determined on UV spectrophotometer. Influence of shaking time (1, 2, 4 and 8 hours) on chromium concentration was also noted and compared with ultrasonic agitation.

\section{Spectrophotometry:}

Sample preparation:

Ten $\mathrm{ml}$ each of the sample was dissolved in $100 \mathrm{ml} \mathrm{K}_{2} \mathrm{HPO}_{4}$ and shaken for three hours. The $\mathrm{pH}$ of the samples was measured. The extract was then filtered through $0.45 \mu \mathrm{m}$ membrane filter paper. Procedure:

Tannery effluents were not diluted in one experiment and one experiment was conducted without 1,5 diphenyl carbazide solution. Ten ml each of the sample ( $\mathrm{pH}$ between $7.5-8.0$ ) was mixed with $1 \mathrm{ml}$ of 1,5 diphenyl carbazide solution and $1 \mathrm{ml}$ of phosphoric acid solution and diluted up to $50 \mathrm{ml}$ with distilled water. After 15 minutes, spectrophotometer readings were taken at $540 \mathrm{~nm}$ wavelengths against potassium chromate as standard. The same procedure was used, but with exception that the samples were not diluted in one experiment and one experiment was conducted without 1,5 diphenyl carbazide due to its interference effect on coloured species. 
Recovery of chromium from the tannery wastewater by use of Bacillus subtilis in Gujranwala,

Extraction of $\mathrm{Cr}$ (Vi) - HCl complex with MIBK (methyl iso-butyl ketone):

Chromium (VI) forms the complex $\mathrm{HCrO}_{3} \mathrm{Cl}$ with $\mathrm{HCl}$, which may be extracted with MIBK. The complex stability is affected by temperature and therefore cooling to $277 \mathrm{~K}$ is required to assure its stability. The following procedure was used:

Forty $\mathrm{ml}$ of the sample-A, $4.0 \mathrm{ml}$ of concentrated $\mathrm{HCl}$ and $5.0 \mathrm{ml}$ of MIBK (Methyl iso-butyl ketone) were added. The mixture was shaken for one minute and the phases were allowed to separate. Before applying the MIBK (Methyl iso-butyl ketone) extraction procedure all the samples, reagents and laboratory ware were cooled to the same temperature $(277 \mathrm{~K})$. Cr (VI) was determined immediately in the organic phase on UV spectrophotometer. One $\mathrm{ml}$ of $\mathrm{L}$-ascorbic acid was added to compensate for possible interference due to $\mathrm{Cr}$ (III). The same process was employed to the sample-B.

Fractionation and Determination of $\mathrm{Cr}(\mathrm{VI})$ :

Fractionation of chromium was performed by various sequential extraction procedures. Modified method of Taylor et al. (1998) was followed.

Determination of Hexavalent Chromium:

Potassium chromate $\left(\mathrm{K}_{2} \mathrm{CrO}_{4}\right)$ was used as standard chromium (VI) determinant. Modified method of Ramesh Kumar and Riyazuddin (2009) was used.

\subsubsection{Recovery of Chromium Using the Enzyme}

Bacillus subtilis used for the recovery of chromium was isolated from the wastewater samples along with other microbes. It was identified and checked for its proteolytic activity.

\section{Organism:}

The two strains of the Bacillus subtilis were used in this study to recover the hexavalent chromium from tannery effluents. Strain $S_{1}$ was isolated from tannery waste water (Sample B) and strain $S_{2}$ was isolated from the soil near by the laboratory. The isolation and identification of Bacillus subtilis was carried through biochemical tests described in an earlier study ${ }^{[14]}$. The two bacterial strains were routinely maintained on nutrient agar medium.

\section{Materials:}

Tween- 20 (a non-ionic surfactant), $\mathrm{NaOH}, \mathrm{MgO}, \mathrm{H}_{2} \mathrm{SO}_{4}$, enzyme extract, waste water samples

\section{Production of the Enzyme:}

Screening test for proteolytic activity was performed on both the strains of the Bacillus subtilis using sample plate technique in which zones of protein hydrolysis around the bacterial colonies were observed and the proteolytic activity was correlated with the zones of protein hydrolysis. Luria Casein Agar plates (1\%) were used for this purpose. Sterilized plates of $1 \%$ Luria Casein Agar were inoculated with the bacterial cultures using sterilized needle. After 24 hours of inoculation at $37^{\circ} \mathrm{C}$, clear zone of hydrolysis were formed around each bacterial colony. The plates were flooded with $10 \%$ glacial acetic acid, which made the zones around the bacterial colonies more prominent. After 15 minutes the diameter of each zone of hydrolysis was measured.

\section{Inoculum Preparation:}

Glucose minimal medium $(250 \mathrm{ml})$ was poured in three $1000 \mathrm{ml}$ Erlenmeyer flasks; $\mathrm{pH}$ of the medium was adjusted at 7.0 by using $0.1 \mathrm{~N}$ sodium hydroxide and $0.1 \mathrm{~N}$ acetic acid. The medium was then autoclaved at $121^{\circ} \mathrm{C}$ for 20 minutes. The medium was cooled and inoculated with 2 loops full of each culture $\left(\mathrm{S}_{1}\right.$ and $\left.\mathrm{S}_{2}\right)$. These flasks were then placed in incubator shaker at $37^{\circ} \mathrm{C}$ for 24 hours at $120 \mathrm{rpm}$.

\section{Fermentation for the Crude Enzyme Production:}

The Bacillus subtilis did batch culturing in the Shake Flask for fermentation to produce extra cellular proteases. In two $2800 \mathrm{ml}$ Fern batch flasks, $1000 \mathrm{ml}$ of glucose minimal medium (pH 7.5) was poured and autoclaved at $121^{\circ} \mathrm{C}$ for 20 minutes. Both the inoculums $S_{1} \& S_{2}(100 \mathrm{ml}$ each) were added in different flasks. These flasks were then placed in shaking incubator at $37^{\circ} \mathrm{C}$ and $150 \mathrm{rpm}$ for 72 hours. The samples were collected after every 12 hours. The strain $\mathrm{S}_{2}$ of the Bacillus subtilis that gave maximum proteolytic activity of $107 \mathrm{PU} / \mathrm{ml}$ was used for further studies

\section{Enzyme Assay:}

The method of Kunitz (1965) was followed for the measurement of proteolytic activity of the extra cellular proteases. One $\mathrm{ml}$ of the $1 \%$ casein solution in tris buffer $(\mathrm{pH} 8.5)$ was mixed with $1 \mathrm{ml}$ of the crude enzyme extract ( $\mathrm{pH} 8.5)$. The mixture was incubated at $40^{\circ} \mathrm{C}$ for 30 minutes. Then $3 \mathrm{ml}$ of $0.3 \mathrm{M}$ trichloroacetic 
Recovery of chromium from the tannery wastewater by use of Bacillus subtilis in Gujranwala, acid (TCA) was added and the tubes were placed in ice for 15 minutes. The precipitates were removed by centrifugation at $10,000 \mathrm{rpm}$ at $4{ }^{\circ} \mathrm{C}$ for 30 minutes. The standard was prepared in the same way except that $3 \mathrm{ml}$ TCA was added before incubation. All assays were made in triplicate (One unit of activity is defined as that amount of the enzyme which releases $1 \mu \mathrm{g}$ of tyrosine under assay conditions. $\left(\mathrm{pH} 8.5\right.$, temperature $40^{\circ} \mathrm{C}$ and 30 minutes incubation period).

\section{Application of the Enzyme:}

Maximum enzyme production was carried out at all optimum conditions for 48 hours. The medium was then centrifuged at 10,000 rpm for 20 minutes at $4^{\circ} \mathrm{C}$. The enzyme solution having $107 \mathrm{PU} / \mathrm{ml}$ proteolytic activity, used for the recovery of chromium from tannery wastewater. Both the samples (A \& B) of the tannery wastewater were used for the chromium recovery.The tannery wastewater, along with tween-20 and $6.0 \mathrm{~g} \mathrm{MgO}$ was reheated at $65^{\circ} \mathrm{C}$ for 2 hours. The enzyme extract was then added in it and allowed to settle for 3 hours. After the enzyme digestion $\left(65^{\circ} \mathrm{C}\right.$ for three hours), the sample was pumped hot in porcelain funnel using Whatman \# 1 filter paper; the solution was allowed to settle overnight. The upper protein hydrolysate layer was separated and the lower chromium layer was filtered through Whatman \# 1 filter paper. Protein layers were stored $4^{\circ} \mathrm{C}$. The unwashed chrome cake was collected and stored at $4^{\circ} \mathrm{C}$.

\section{Recovery of Chromium from the One-Step Process:}

Both the samples (A \& B) of the tannery wastewater were used for the chromium recovery. The tannery wastewater, along with tween- 20 and $6.0 \mathrm{~g} \mathrm{MgO}$ was reheated at $65^{\circ} \mathrm{C}$ for 2 hours. The enzyme extract was then added in it and allowed to settle for 3 hours. After the enzyme digestion $\left(65^{\circ} \mathrm{C}\right.$ for three hours), the sample was pumped hot in porcelain funnel using Whatman \# 1 filter paper; the solution was allowed to settle overnight. The upper protein hydrolysate lawyer was separated and the lower chromium layer was filtered through Whatman \# 1 filter paper. Protein layers were stored $4^{\circ} \mathrm{C}$. The unwashed chrome cake was collected and stored at $4^{\circ} \mathrm{C}$.

\section{Recovery of Chromium from the Two-Step Process:}

In step one of the Two-step processes $100 \mathrm{ml}$ each of the sample (A \& B) was mixed with $0.2 \mathrm{ml}$ Tween-20, $6.0 \mathrm{~g} \mathrm{MgO}$ and $500 \mathrm{ml}$ distilled water in $2 \mathrm{~L}$ Erlenmeyer flask each. These flasks were than put in the shaker for 6 hours at $70-72^{\circ} \mathrm{C}$. The samples were then centrifuged hot at $10,000 \mathrm{rpm}$ for 20 minutes and the supernatant was filtered through Whatman \# 1 filter paper. The chrome sludge (supernatant) and gelable protein (filtrate) were stored at $4{ }^{0} \mathrm{C}$. In the second step, the chrome sludge was warmed to room temperature and hundred percent chrome sludge was added to $200 \mathrm{ml}$ distilled water and than $0.1 \mathrm{ml}$ non-ionic surfactant (Tween-20) $0.2 \mathrm{~g}$ alkali $(\mathrm{MgO})$ was added to it. These flasks were shaken for 1.5 hours to obtain maximum solubility at $70-72^{\circ} \mathrm{C}$. The $\mathrm{pH}$ was adjusted with $\mathrm{MgO}$ to the optimal $\mathrm{pH}$ for the enzyme. The enzyme $(50 \mathrm{ml})$ was added and the sample was again shaken for 3.5 hours at $70-72^{\circ} \mathrm{C}$. The solution was filtered hot through Whatman \# 1 filter paper and the protein solution was stored at $4^{0} \mathrm{C}$. The chrome cake was air-dried.

\section{Treatment of the Chrome Cake:}

Air-dried chrome cake $(1 \mathrm{~g})$ was dissolved in $50 \mathrm{ml}$ of $3.6 \mathrm{~N}(23 \%)$ sulfuric acid. The $\mathrm{pH}$ was less than 1.0. The $\mathrm{pH}$ of the solution was slowly raised to $1.85-2.00$ with sodium hydroxide (50\% w/w solution). A flocculated precipitate formed that coagulated, when the solution was heated for several minutes at $60^{\circ} \mathrm{C}$. The solution was allowed to stand overnight at ambient temperature and was than filtered. The residue was washed with $0.01 \mathrm{~N}$ sulfuric acid to remove trapped chromium. The residue was dried overnight at $60^{\circ} \mathrm{C}$ and weighed; the percent residue was calculated. Percent moisture was calculated by heating at $105^{\circ} \mathrm{C}$ for 17 hours. The residue was ash-dry at $600^{\circ} \mathrm{C}$ in oven and percent ash was calculated.

\section{Results}

\section{Determination of Total Water-Soluble Cr AND Cr (VI) in the Tanning Effluents:}

Cr (VI) investigated in the samples was found to be $46 \mu \mathrm{g} / \mathrm{ml}$ in the sample-A and $68 \mu \mathrm{g} / \mathrm{ml}$ in the sample-B. Total water-soluble $\mathrm{Cr}$ in the sample-A was $50 \mu \mathrm{g} / \mathrm{ml}$ and $81 \mu \mathrm{g} / \mathrm{ml}$ in the sample-B. The influence of shaking time on the concentration of total water- soluble $\mathrm{Cr}$ and $\mathrm{Cr}$ (VI) was studied (Table-1).

Comparison between Classical Shaking and ultrasonic Agitation on Determination of Total WaterSoluble $\mathrm{Cr}$ and $\mathrm{Cr}(\mathrm{VI})$ in the Samples:

The results are presented in Table-1. It is evident that the concentration of total water-soluble $\mathrm{Cr}$ and $\mathrm{Cr}$ (VI) are higher with classical shaking than with ultrasonic agitation. 
Recovery of chromium from the tannery wastewater by use of Bacillus subtilis in Gujranwala,

Spectrophotometry

The results of spectrophotometer method compared to the MIBK (Methyl iso-butyl ketone) extraction method are presented in Table-2.

\section{Fractionation of Chromium in Tannery Wastewater:}

The tannery wastewater was fractionated to determine the distribution of chromium species between various compounds. The results are presented in Figure 1-a. It is evident from Figure-1 (standard graph) that tannery waste water contained high concentration of chromium.

\section{Determination of Hexavalent Chromium:}

The results presented in Table-3 shows the hexavalent chromium was present in quite an amount in tannery waste water.

\section{Production of the Enzyme for Chromium Recovery: Qualitative Test:}

Ability of the two strains of the Bacillus subtilis $\left(\mathrm{S}_{1}\right.$ and $\mathrm{S}_{2}$ ) to produce extra cellular protease enzyme was determined by measuring the diameter of zone of hydrolysis on 1\% Luria Casein Agar plates around each colony. Table 4-a shows the results.

Shake flask fermentation of the bacillus subtilis for protease production:

The Shake Flask Fermentation was employed to check the production of protease enzyme by the Bacillus subtilis for 72 hours. The results are shown in Table 4-b.

\section{Optimum Temperature and pH for the Enzyme Extract:}

The proteolytic activity of the crude enzyme extract was stable upto $84 \%$ at $50^{\circ} \mathrm{C}$ and then there was sharp decrease in proteolytic activity with further increase in temperature and it was $38 \%$ at $80^{\circ} \mathrm{C}$. Table 4-c shows the effect of $\mathrm{pH}$ on proteolytic activity and Table 4-d shows the effect of temperature on proteolytic activity. Table 4-e shows the optimum ph for maximum proteolytic activity .

\section{Recovery of chromium from the One-step process:}

Table 5-a shows the amount of chromium recovered from both samples using the one step method. Chemical composition of recovered chrome cake is shown in Table 5-b.

\section{Recovery of chromium from the Two-step process:}

Sample-A showed the maximum recovery. The results are shown in Table 6-a. The recovered chrome cake was analyzed for moisture and ash content (Table 6-b).

\section{Treatment of Chrome Cake:}

Table 5-b and Table 6-b shows the results of treated chrome cake. The chrome cake was also characterized for its residue; the result is shown in Table 7.

\section{Discussion}

$\mathrm{Cr}$ (III) salts are efficiently used as tanning agents in the leather industry. When the waste is disposed off on soil, the risk of potential oxidation of some Cr (III) species to the hazardous hexavalent state exists in the presence of manganese (IV) oxide. Recovery of chromium is one of the options to make leather industry environmental friendly.

The samples were collected from two Tanneries in Gujranwala, Pakistan and were tested for the presence and recovery of chromium. Taking into account the large volume of wastewater containing very high chromium concentrations and the difficulties in finding proper disposal sites for the sludge produced, many countries have turned to "clean" technologies including chromium recovery and reuse. It was investigated that common basic compounds could precipitate $\mathrm{Cr}$ (III) but the settling characteristics of the precipitate formed by the reaction of $\mathrm{MgO}$ were superior due to its minimum sludge volume ${ }^{[38 \& 12] \text {. }}$

The parameters influencing the extraction efficiency of total water-soluble $\mathrm{Cr}$ and $\mathrm{Cr}$ (VI) were investigated in the tannery wastewater. Water and $\mathrm{KH}_{2} \mathrm{PO}_{4}$ solution $\left(0.015 \mathrm{~mol} / \mathrm{dm}^{3}\right)$ were used as extractants. The latter, being an electrolyte, adsorbs $\mathrm{Cr}(\mathrm{VI})$ from the samples. Membrane filters of $0.1 \mu \mathrm{m}$ pore size were used for the efficient removal of $\mathrm{Cr}(\mathrm{VI})$, when using potassium dihydrogen phosphate as an extractant and 0.05 $\mu \mathrm{m}$ filters when using water as an extractant. The equilibrium of total water-soluble chromium between solid and liquid phases was achieved after two hours of shaking in the classical shaker with potassium dihydrogen phosphate as an extractant and after eight hours when water was used as an extractant. Five minutes of ultra sonic agitation was very convenient for the tanning effluents. In actual practice, $20 \mathrm{ml}$ of extractant and $2.0 \mathrm{ml}$ 
Recovery of chromium from the tannery wastewater by use of Bacillus subtilis in Gujranwala,

of the sample were used for the determination of total water-soluble $\mathrm{Cr}$ and $\mathrm{Cr}$ (VI) (Table-1). The above used method was compared with the method used in study ${ }^{[11]}$ which optimized the extraction procedure for determination of total water-soluble $\mathrm{Cr}$ and $\mathrm{Cr}(\mathrm{VI})$ and found that $\mathrm{Cr}$ extracted through classical shaking was in greater concentration than that by ultrasonic agitation.

Chromium was extracted with diphenyl carbazide ${ }^{[13,35 \& 37]}$ in presence of other metals after separation by solid phase extraction. Amongst the various analytical techniques spectrophotometry has been widely used for determination of $\mathrm{Cr}(\mathrm{VI})$ in different sample matrices ${ }^{[17]}$.

Table-2 shows that concentration of total chromium ranged from 280 to $364 \mathrm{mg} / \mathrm{L}$ and that the $\mathrm{pH}$ of both the samples was from 4.5 to 8.9. It is also evident from these results that results obtained by spectrophotometry are in general much higher than those obtained by the MIBK (Methyl iso-butyl ketone) extraction technique. The reason for this lies in the non-specific reaction of diphenyl carbazide reagent with the sample that resulted in the development of the coloured species, which gave non-specific absorption at $540 \mathrm{~nm}$. The results $2.10 \mathrm{mg} / \mathrm{L}$ in case of the sample-A and $3.85 \mathrm{mg} / \mathrm{L}$ in case of the sample-B calculated from the fivefold diluted sample were even higher than those for non-diluted samples. On the basis of these observations it can be said that spectrophotometry over estimates the results for $\mathrm{Cr}$ (VI) in coloured watewater samples. Therefore, the results obtained are not reliable, even though it was recommended spectrophotometry in DIN 533314 method $^{[17]}$, standard for the analysis of $\mathrm{Cr}(\mathrm{VI})$ in tannery wastewater. Reliable results were obtained by MIBK (Methyl iso-butyl ketone) extraction technique, which was sensitive enough and was not liable to interference effects in the sample matrix analysed. MIBK extraction for determination of chromium from tannery polluted water is also used in other studies ${ }^{[23 \& 24]}$. Therefore, the latter technique was found to be suitable for determination of $\mathrm{Cr}(\mathrm{VI})$ in the tannery wastewater.

It is evident from the results shown in Table 2-a that concentration of total chromium in the tannery waste was very high and the prevailing chromium fraction was hydroxylamine hydrochloride extractable. Second largest quantity of chromium was bound to organic molecules. Acetic acid extractable fraction contained the third largest quantity of chromium. Compared to these, substantially more chromium exists in the watersoluble potassium dihydrogen phosphate $\left(0.015 \mathrm{~mol} / \mathrm{dm}^{3}\right)$, and exchangeable fractions, while nitric acid (1 mol $/ \mathrm{dm}^{3}$ ) extractable and mineral fractions were negligible. Fractionation and oxidation of chromium in the tannery waste and found that $\mathrm{KH}_{2} \mathrm{PO}_{4}(0.085 \mu \mathrm{g} / \mathrm{g})$ contained less amount of chromium and hydroxylamine hydrochloride was the largest fraction extracted from the samples ${ }^{[16]}$. Isolates for potential of chromium removal in minimal salt medium containing different fractions was screened in another study ${ }^{[26]}$.

Bacillus subtilis secretes proteolytic enzymes, which can be used in recovery of chromium. Culture broth (whole fermentation broth) along with bacterial mass was used for the biotreatment of the tannery effluents. In the samples Bacillus subitilis was confirmed by morphological and biochemical tests. The ability of the two Bacillus subtilis strains $\left(\mathrm{S}_{1} \& \mathrm{~S}_{2}\right)$ obtained from soil and the tannery wastewater were checked for the production of extracellular proteases on 1\% Luria Casein Agar plates. Both strains showed proteolytic activity but the strain $\mathrm{S}_{2}$ of the Bacillus subtilis isolated from the tannery wastewater showed maximum $(2.3 \mathrm{~cm})$ zone of hydrolysis (Table 4-a). In "Shake Flask Batch Culturing" the $\mathrm{S}_{2}$ strain of the Bacillus subtilis showed maximum proteolytic activity activity of $107 \mathrm{PU} / \mathrm{ml}$ after 48 hours of incubation, so it was selected for further studies (Table 4-b).

Maximum proteolytic activity was achieved at initial $\mathrm{pH}$ 7.5. These results correlate with the observation ${ }^{[27 \& 30]}$ in which maximum proteolytic activity with an initial $\mathrm{pH} 7.6$ and temperature $37^{\circ} \mathrm{C}$ by the Bacillus alcalophilus sub spp. Haldurans was obtained. Thermostability of the crude enzyme extract was tested and observed that the enzyme was stable up to $70^{\circ} \mathrm{C}$ after one hour of incubation. Enzymes play an important role in the tanning of hides and skins ${ }^{[15]}$. A process was established ${ }^{[28 \& 29]}$ that could help leather industry in solving the potentially difficult waste disposal problem, the chrome waste was treated with the alkaline protease enzymes at moderate temperature for a short period of time. The $\mathrm{pH}$ at which the reaction took place (8.3 to 8.5) prevented the chromium from going into the solution, thus averting the poisoning of the enzyme by chromium and enabling the recovery of chromium as $\mathrm{Cr}(\mathrm{OH})_{3}$ by filtration. The resulting protein solution may have commercial use as a feed or a fertilizer. The isolated chrome cake may potentially be recycled into the tanning process by treatment with sulphuric acid. Broad specificity of the enzyme and its stability at high temperature in alkaline conditions helped this enzyme to be used in the biotreatment of the tannery wastes [3].

In the One-step process the tanning effluents were heated for 2 hours at $65^{\circ} \mathrm{C}$ to achieve optimal solubility (Table 5-a). Composition of the chrome cake was studied. The chrome cake was tested for its moisture, ash and chromic oxide content (Table 5-b). Maximum recovery of chromium was obtained from the Two-Step Process at agitation speed of $150 \mathrm{rpm}$, temperature $72^{\circ} \mathrm{C}$ and $\mathrm{pH} 8.5$ (Table 6-a). The chrome cake was treated chemically using sulphuric acid. Then it was analysed for moisture and ash content (Table 6-b). The percent recovery of chromium in the sample-A was $98 \%$ and $97 \%$ in case of the sample-B. 
Recovery of chromium from the tannery wastewater by use of Bacillus subtilis in Gujranwala,

\section{Conclusion:}

The present bench scale study offers a method to acquire pure chromium from chromium loaded waste of tanneries. Maximum amount of this (upto 98\%) can be recovered from the tannery wastewater, for which microbiological methods can be employed. The chromium produced is cost effective. The recovered chromium can also be used as retanning agent as well as in cements and mortars. Use of proteolytic enzymes to recover chromium can help in controlling many diseases. Furthermore, the environment pollution because of chromium can be minimized.

\section{References}

[1]. Abass. Esmaeili, Alireza. Mesdaghi nia, and Reza. Vazirinejad, (2005). Chromium (III) removal and recovery from tannery waste water by precipitation process. American Journal of Applied Sciences, 2005, 2 (10): 1471.

[2]. Amita D. Apte, Shubham Verma, Vinod Tare, Purnendu Bose, Oxidation of Cr (III) in tannery sludge to Cr (VI): Field observations and theoretical assessment (2005). J. Hazard Mater. 121, (1-3) : 215-222.

[3]. Brady D, Duncan JR and Russel AE (1990). A model of proteolytic depletion of skins. JALCA. 1990, 85, $334-343$.

[4]. Brown EM, Diefendorf EM, Taylor MM, Marmer WN (1993). Enzymatic processing of materials containing chromium and protein. J. U.S. Patent. 5, 912, 946, (CA 107: 242425n).

[5]. Cot J. (2004). An imaginary journey to the collagen molecule for better understanding of leather waste treatments. JALCA, 2004, $88,322-350$.

[6]. Dermou E, Velissariou J, Xenos D and Vayenas DV (2005). Biological chromium (VI) reduction using a trickling filter. J. Hazard. Mater. 26, 78-85.

[7]. Faryal R,Yusuf M, Munir K, Tahir F and Hameed A (2007). Enhancement of Cr6+ removal by ASPERGILLUS NIGER RH19 using a biofermentor. Pak. J. Bot., 39(5): 1873-1881.

[8]. Gopalan R, Veeramani H (1994). Studies on microbial chromate reduction by Pseudomonas sp. in aerobic continuous suspended growth cultures. J. Biotech. Bioeng. 43 471-476.

[9]. Kadirvelu K and Thamaraiselvi CN (2001). Removal of heavy metals from industrial wastewaters by adsorption onto activated carbon prepared from an agricultural solid waste, Bioresour. Technol 76 63-65.

[10]. Kamlesh N, Dharam S, Shilpa S and Sharma YK (2009). Phytotoxic effects of chromium and tannery effluent on growth and metabolism of Phaseolus mungo Roxb. J. Environ. Biol. 30(2), 227-234

[11]. Kozuh J, Stupar J, Milacic R, Gorenc B (1993). Optimization of extraction for determination of total water-soluble chromium \& chromium (VI) in various soils. J.Anal.Chem.56, 207-217.

[12]. Langerwerf JSA (1978). Recovery \& reuse of trivalent chromium. J. Proc. Conger. Leather. Ind. 1, 251-261.

[13]. Lobat-Estelle's M, Mauri-Aucejo AR, Lope-Caterian MD (2001). Spectrophotometric determination of chromium with diphenyl carbazide in the presence of vanadium, molybdenum and iron after separation by solid phase extraction. Fresenius $\mathbf{J}$ Anal Chem 2001, Oct:371 (3), P: 358-63.

[14]. Mary MS, Judy Gopal, Tata BVR, Rao TS and Vincent. S (2008). A confocal microscopic study on colony morphology and sporulation of Bacillus sp. World J. Microbiol. Biotechnol., 24 (2008), pp. 2435-2442.

[15]. Malathi S \& Chakarborthy R (1991). Production of alkaline protease by Aspergillus flavis for use as a depletion agent. J. Appl. Environ. Microbiol. 57, 712-716.

[16]. Milacic R \& Stupar J (1995). Fractionation \& oxidation of chromium in tannery waste \& sewage sludge-amended soils. J. Environmental Science \& Technology .29, 506-515.

[17]. Milacic R, Scancar J, Urbanc M (1998). Is spectrophotometry a reliable technique for determination of chromium (VI) in leather samples? J. Soc. Leather. Tech. \& Chem.82, 91-94.

[18]. Munoz R, Guieysse B (2006). Algal-bacterial processes for the treatment of hazardous contaminants: a review, Water Res. 40 2799-2815.

[19]. Munoz RMT, Alvarez A. Munoz E, Terrazas B et al., (2006). Sequential removal of heavy metals ions and organic pollutants using an algal-bacterial consortium, Chemosphere 63 903-991.

[20]. Okamoto Y and Katono S. (1974). J. Japan Patent. 74, 358.

[21]. Pena-Castro JM, Mart FN, Esparza-Garca F, Canizares-Villanueva RO (2004). Heavy metals removal by the microalga Scenedesmus incrassatulus in continuous cultures, Biores. Technol. 94. 219-222.

[22]. Prasenjit B and Sumathi S (2005). Uptake of chromium by Aspergillus foetidus, J. Mater. Cycles Waste Manag. $788-92$

[23]. Ramesh Kumar A, Riyazuddin P (2009). The effect of Cr (III)-organic complexes on the determination of inorganic chromium species in ground water by ammonium pyrrolidinedithiocarbamate-methylisobutylketone extraction procedure J. Microchemical. 92 (2) $145-149$.

[24]. Ramesh Kumar A, Riyazuddin P (2010). Chromium speciation in ground water of tannery polluted area of Chenai City, India. J. Enviro. Monit. Assess. 160. 579-591.

[25]. Report on Carcinogens Eleventh Edition (Jan 2009). U.S department of Health and Human services, Public Health Service, National Toxicology Program (NTP) 2009.

[26]. Srivastava Shaili, Ahmad AH, Thakur IS (2006). Removal of chromium and pentachlorophenol from tannery effluents. . doi:10.1016/j.biortech.2006

[27]. Shankar C, Sridevi D, Joonhong P, Michael D, Kaliannan T (2007). Biosorption of chromium and nickel by heavy metal resistant fungal and bacterial isolates. J. Hazard Mater. 146. 270-277

[28]. Sinha S, Saxena R and Singh S (2005). Chromium induced lipid peroxidation in the plants of Pistia stratiotes L. Role of antioxidants and antioxidants enzymes. Chemosphere, 58, 595-604

[29]. Sukumar M (2010). Reduction of hexavalent chromium by Rhizopus Oryzae. African J of Envir Science and Tech. Vol. 4(7), pp. 412-418.

[30]. Taki Y, Kuriyama N and Suzuki (1990). Alkaline serine proteases produced from citric acid by Bacillus alkalophillus sub spp.haldurans KP 1239.J.Appl.Microbiol.Biotech.34,57-62.

[31]. Taylor MM, Diefendorf EJ, Brown EM, Marmer WN (1992). Enzymatic processing of materials containing chromium and protein. J.U.S.Patent. 5, 094, 946, (CA 117:219303u).

[32]. Taylor MM, Diefendorf EJ, Brown EM, Marmer WN (1994). Characterization of products isolated by enzymatic treatment of chromium containing leather waste. JALCA. 87, 380-388.

[33]. Taylor MM, Diefendorf EJ, Brown EM, Cabeza LF (1996). Extraction of chromium containing collagenous leather industry waste. JALCA. 81, 5-12. 
Recovery of chromium from the tannery wastewater by use of Bacillus subtilis in Gujranwala,

[34]. Terres E, Cid E, Herrero JA (1998). Removal of cadmium ions by the marine diatom Phaeodactylum tricornutum Bohlin accumulation and long-term kinetics of uptake, Biores. Technol. 63 213-220.

[35]. Telepcakova M, Andruch V, Balogh IS (2005). Indirect extraction -Spectrophotometric determination of chromium. J. chem. Pep 52(2) $109-112$

[36]. UNIDO - Regional Programme for Pollution Control in the Tanning Industry in South-East Asia "Chrome Management in the Tanyard", 2000, http://www.unido.org/userfiles/PuffK/L_chrome_management.pdf

[37]. Wrobel K, wrobel K, Lopez-de-Alba PL, Lopez Martinez L (1997) Enhanced spectrophotometric determination of chromium (Vl) with diphenyl carbazide using internal standard and derivative spectrophotometry (1997). J. Talanta 44 (11) 2129-2136.

[38]. Wood B (1992). Clean technology options in the leather tanning industry, Seminar on the profitability of clean technology in the leather tanning industries,20-21 Oct, Thailand.

[39]. Yan G, Viraraghavan T (2003). Heavy metal removal from aqueous solution by fungus Mucor rouxii, Water Res. 37. 4486-4496.

Table-1

Comparison between ultrasonic homogenization and classical shaking.

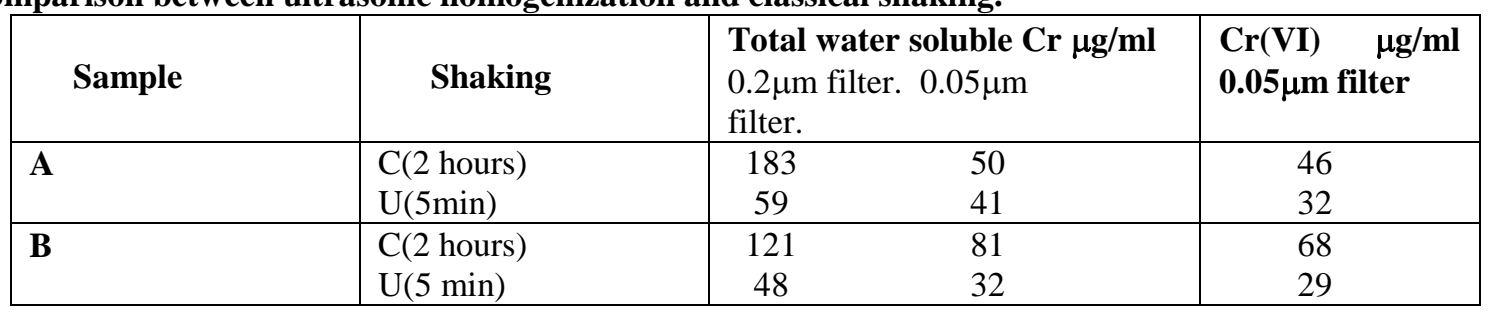

C. Classical Shaker.

U. Ultrasonic homogenizer.

Table-2

Total $\mathrm{Cr}$ in tannery wastewater samples by spectrophotometric method.

\begin{tabular}{|l|l|l|lc|c|}
\hline $\begin{array}{l}\text { Colour of } \\
\text { samples }\end{array}$ & pH of samples & $\begin{array}{l}\text { Total Cr in } \\
\text { samples } \\
\text { mg/L }\end{array}$ & $\begin{array}{l}\text { Cr (VI) in samples by } \\
\text { spectrophotometic method } \\
\text { mg/L Non-diluted diluted } \\
(\mathbf{1 0} \text { ml) }\end{array}$ & $\begin{array}{l}\text { Cr } \mathbf{5 0 m l}) \\
\text { samplesbyMIBK } \\
\text { Extraction procedure } \\
\text { mg/L }\end{array}$ \\
\hline $\begin{array}{l}\text { Dark } \\
\text { bluish } \\
\text { green }\end{array}$ & 4.5 & 364 & 1.98 & 2.10 & 0.351 \\
\hline $\begin{array}{l}\text { Light } \\
\text { yellow }\end{array}$ & 8.9 & 280 & 1.05 & 3.85 & 0.198 \\
\hline
\end{tabular}

Table - 3.

Determination of Hexavalent Chromium.

\begin{tabular}{|c|c|c|c|}
\hline Sample & Shaking Time & $\mathbf{p H}$ after shaking & $\mathbf{C r}(\mathbf{V I}) \boldsymbol{\mu g} / \mathbf{m l}$ \\
\hline A & 24 & 5.6 & 0.101 \\
\hline B & 24 & 7.3 & 0.054 \\
\hline
\end{tabular}

Table 4-a.

Proteolytic activity shown by Bacillus subtilis by forming zones of hydrolysis.

\begin{tabular}{|l|l|l|}
\hline Strains & Source & Zone of hydrolysis cm \\
\hline $\mathrm{S}_{1}$ & Soil & 1.9 \\
\hline $\mathrm{S}_{2}$ & Tannery wastewater & 2.3 \\
\hline
\end{tabular}

Table 4-b

Proteolytic activity of Bacillus subtilis in shake flask culture.

\begin{tabular}{|c|lccr|}
\hline & \multicolumn{4}{|l|}{ Proteolytic Activity PU/ml } \\
Bacterial Strain & 24 hours & 48hours & 72 & hours \\
\hline $\mathrm{S}_{1}$ & 19 & 58 & 43 & \\
\hline $\mathrm{S}_{2}$ & 28 & 93 & 71 \\
\hline
\end{tabular}

Table 4-c.

Effect of pH on Protease Production.

\begin{tabular}{|c|c|l|}
\hline Initial $\mathrm{pH}$ & Final $\mathrm{pH}$ & Proteolytic activity PU/ml \\
\hline 7.0 & 9.0 & 97 \\
\hline 7.5 & 8.8 & 107 \\
\hline
\end{tabular}


Recovery of chromium from the tannery wastewater by use of Bacillus subtilis in Gujranwala, Table 4-d.

Effect of Temperature on Protease Production

\begin{tabular}{|c|c|c|}
\hline Temperature $^{\mathbf{0}} \mathbf{C}$ & Proteolytic Activity PU/ml & Stability (\%) \\
\hline 4 & 122 & 100 \\
\hline 30 & 110 & 94 \\
\hline 40 & 101 & 89 \\
\hline 50 & 97 & 85 \\
\hline 60 & 85 & 79 \\
\hline 70 & 40 & 65 \\
\hline 80 & 15 & 38 \\
\hline
\end{tabular}

Table- 4-e

Optimum pH for Maximum Proteolytic Activity

\begin{tabular}{|l|l|}
\hline pH & Proteolytic Activity PU/ml \\
\hline 7 & 76 \\
\hline 7.5 & 88 \\
\hline 8 & 93 \\
\hline 8.5 & 107 \\
\hline 9 & 98 \\
\hline 9.5 & 92 \\
\hline 10 & 83 \\
\hline
\end{tabular}

Table 5-a.

Amount of Chromium Extracted from One-Step Process

\begin{tabular}{|l|l|l|}
\hline Samples & Amount of Cr. g & \% Recovery \\
\hline A & 9.628 & 96.23 \\
\hline B & 9.213 & 92.13 \\
\hline
\end{tabular}

Table 5-b.

Chemical Composition of Chrome Cake

\begin{tabular}{|l|c|c|}
\hline Parameter (\%) & Sample A & Sample B \\
\hline Moisture & 31.5 & 33.5 \\
\hline Ash & 4.99 & 5.38 \\
\hline Chrome oxide & 9.63 & 9.21 \\
\hline
\end{tabular}

Table 6-a.

Amount of Chromium extracted from Two-Step Process.

\begin{tabular}{|c|c|c|}
\hline Samples & Amount of Cr (g) & \% Recovery \\
\hline A & 9.81 & 98.1 \\
\hline B & 9.74 & 97.4 \\
\hline
\end{tabular}

Table 6-b.

Analytical Tests for Chrome Sludge Obtained from Two-Step Process.

\begin{tabular}{|l|l|ll|}
\hline Parameter (\%) & Sample A $\quad$ (g) & Sample B & (g) \\
\hline Gel extraction & & & \\
step. & & & \\
Chrome sludge: & 83.71 & 84.01 & \\
Moisture & 20.10 & 21.21 & \\
Ash & 32.1 & 37.00 & \\
Protein & & & \\
\hline Hydrolysis step. & & & \\
Chrome cake: & & & \\
Moisture & 89.31 & 87.42 & \\
Ash & 34.58 & 35.52 & \\
Protein & 50.96 & 52.14 & \\
\hline
\end{tabular}


Recovery of chromium from the tannery wastewater by use of Bacillus subtilis in Gujranwala,

Table 7.

Characterization of Residue from Treatment of Chrome Cake

\begin{tabular}{|c|c|c|c|}
\hline Samples & Final pH & \% Residue & \% Ash \\
\hline A & 1.81 & 9.13 & 0.37 \\
\hline B & 1.85 & 6.33 & 0.18 \\
\hline
\end{tabular}

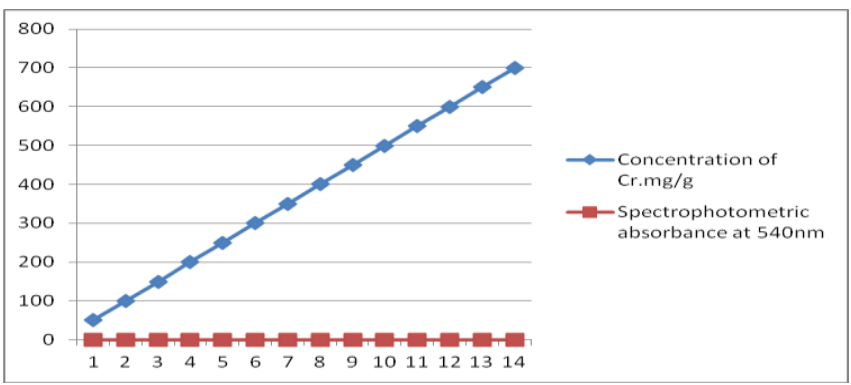

Figure 1. Standard graph.

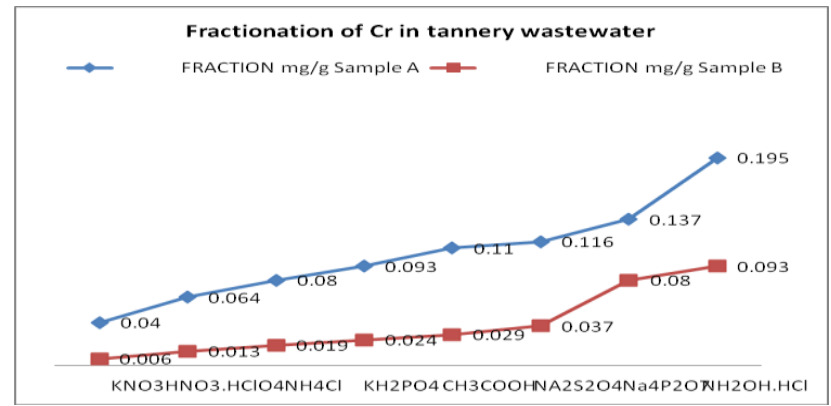

Fig: 1 a: Fractionation of chromium in tannery waste water. 